\title{
The role and professional development of a teacher at a contemporary University
}

\author{
Marina Volodina ${ }^{1, *}$, Natalia Vartanova $^{1}$, and Elzara Tsybenko ${ }^{1}$ \\ ${ }^{1}$ Don State Technical University, Gagarin sq., 1, Rostov on Don, 344003, Russia
}

\begin{abstract}
This article is devoted to the study of the role of the present teacher in the period of transformation of the traditional education system and transition to a digital environment. The article analyzes possible ways and strategies to improve the quality of vocational teacher education in the current conditions. Particular emphasis is given to the necessity of changing the correlations between different components of teaching skills in the digital educational process, as well as the personality and professional competence of the teacher as the most important component of ensuring the success and effectiveness of the educational process in a digital learning environment.
\end{abstract}

\section{Introduction}

The development program of the system of continuous teacher education in Russia, as well as the project "Teacher education 2024" currently define modern approaches to the problem of improving the structure and quality of vocational teacher education.

The staged implementation of the project involves the introduction of a new model of teacher education. The authors of the project emphasize that "over the past two decades, many attempts have been made to modernize teacher education and project support for its development (the Development program of continuous teacher education system in Russia 2001-2010 within the Concept of modernization of Russian education for the period up to 2010. Its "succession was completed" by the Program of modernization of teacher education (the Ministry of Education of the Russian Federation dated 1.04.2003 No. 1313), and then in 2014-2017 the Program of Teacher Education Modernization). However, the continuity between the programs was not ensured properly." It is for this reason that teacher education needs to be reformed. This project sets out the following strategic guidelines:

- improving the quality of teacher education by organizing extensive professional development of teaching staff, administrative and managerial staff and support staff of all universities that implement teacher training programs;

- updating its content and structure based on the formation of a single digital educational space of teacher education;

- introduction of an independent quality assessment system for teacher education;

- ensuring the unity of professional training and education, balance of state, public and personal priorities in the system of continuous teacher education;

*Corresponding author mclavender1984@gmail.com 
- the increasing role of teacher education institutions in solving the problems facing the state and society in the new economic and socio-cultural conditions.

- conducting a complex of interdisciplinary studies of the process of cognitive development, the mental world, motivations and values, psychophysiology of the modern child and the youth of the digital age, on the basis of which to conduct the necessary content update.

\section{Problem statement}

This article is devoted to the issue of the quality of pedagogical activity in the conditions of digital transformation of the educational process. The quality of vocational teacher education is determined not only and not so much by quantitative indicators of training success, but by qualitative criteria for design and analysis of education quality: quality of education sector, educational process, educational activities, implemented digital programs, systems of education management and physical infrastructure aimed at a smooth transition to the digitization of the educational process.

Education from the sphere of transmission and reproduction of already existing cultural forms becomes an environment for purposeful design and development of innovative forms of life.

In the era of the fourth industrial revolution, when the educational process is reconstructed on the widespread use of advanced technologies, it is important to preserve the humanitarian and educational environment in which not only the maximum number of subject-subject relations and communications are updated, but processes of personal development (self-actualization, self-realization, self-development) are implemented too. It is also necessary to update aspects of antropocentrism, integration, complexity, universality, language orientation, and integrity, as a reflection of the highest degree of development of the educational space in the conditions of digitalization.

One of the conceptual directions of the national project "Education" is to define the roles of the teacher and psycho-pedagogical doctrine of professionalization, which is an integral part of continuous teacher education. It is also defined as a process of development of professionally significant qualities and formation of emotional readiness to perform activities in conditions of wide introduction of digital technology, confident skills in digital content incurring the transformation of the system of continuous teacher education and the achievement of the highest level of professional skills through learning of professional competencies and digital skills.

The role of the teacher is in question while distance learning, where a teacher and a student are separated by a significant distance, and the learning process is carried out using mail, television, the Internet, etc. In contrast to the traditional education system, teachers are more focused on the student. They provide standard and individual learning materials for students accompanied by face-to-face meetings and consultations. One of the most important functions of the training staff is to develop, test and implement training means of education, including self - training materials.

The analysis units of the professionalization process in the new reality are the stages of different levels of teacher integration in the digital educational environment: stages, periods (part of the stage), phases (part of the period). Each of the stages is characterized by a situation of professional development; a new personality formation; a specific system of professionally important and significant qualities required for the implementation of this activity.

\section{Findings}


The quality of professional development of an individual is determined by the degree of integration of new personality formation and forms of professional activity (accumulation, interaction, integration of functional systems that provide solutions to specific tasks of professional activity and development).

In the context of digitalization, the search for real ways to improve the quality of vocational teacher education is also associated with existing traditions in pedagogical practice. In this context, we will consider the following practice-oriented strategies for improving the quality of vocational teacher education:

- the technology strategy focuses on the development of skills and practical use of information and communication networks and technologies, the acquisition of necessary knowledge and experience, mastering algorithms for using cloud services, designing interactive models in online learning and teaching activities based on communication skills, motivation and pedagogical creativity. The content of such innovative education should be theoretical and applied knowledge. Thus, one of the most significant aspects of the use of modern applied knowledge is its communicative and technological orientation.

- the system-structural strategy is determined by the need to change the relationship between the individual components of teacher skills. A significant motive, in this context, is the ratio of traditional and innovative components in vocational teacher education, where the traditional component refers to the training of subject teachers as well as the development of personal abilities of the universal teacher, and the innovative one refers to master the special skills in the advanced services in digital environment.

In this regard, the main provisions of the national project "Education" develop tools and technologies of personal-oriented vocational teacher education involving:

- development and implementation of digital educational and methodical complexes based on cloud technologies, visualization technologies, virtual reality;

- modernization of the educational standards system of general and professional education in order to ensure their congruity with the needs of the modern innovative economy;

- development and implementation of educational computer games and digital stimulators, wide use of game mechanics;

- expansion of mass online courses, organization of an open database containing technological educational modules, innovative programs, electronic resources for continuing professional education through modern network technologies. Currently, Russian Universities as a part of the national project "Education" make available more and more online courses on international platforms. Thus, since 2012 the number of online courses from Russian Universities has increased significantly (Fig. 1);

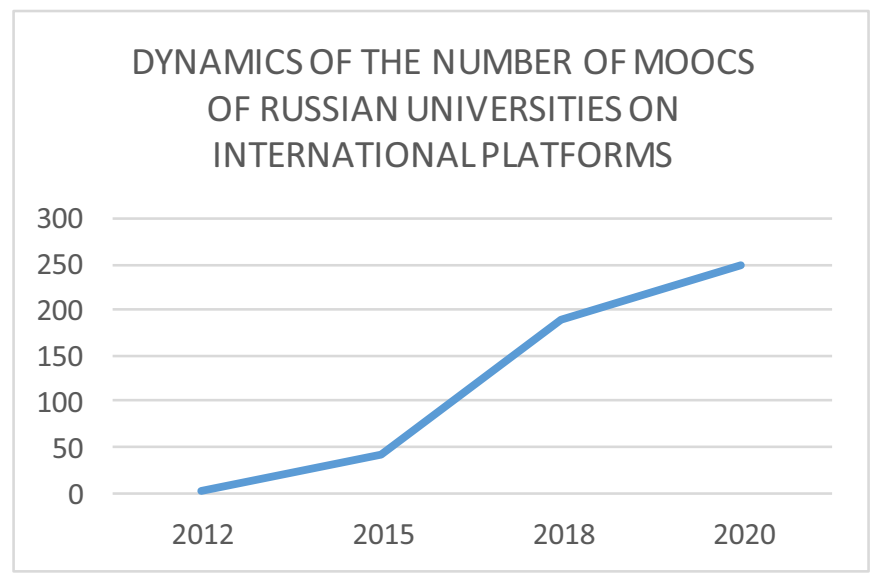

Fig. 1. Dynamics of the number of MOOCS of Russian universities on international platforms 
- introduction of social networks in education that allow for the rapid exchange of information, ensure the formation of new user relationships, and the development of digital communication skills.

The assessing and rating strategy of updating teacher education involves a set of conceptual ideas, scientific and methodological results and managerial measures to create systems of diagnostics and monitoring of quality as a core module of all innovations in professional teacher education. This strategy of improving the quality of professional teacher education is based on the idea of the leading role of an integrated system of factbased diagnostics of the qualities and characteristics of future teachers. In the context of education digitalization, it is possible to introduce a mechanism for assessing the quality of professional education based on the information openness of educational institutions and a permanent system of public monitoring (with the participation of representatives of employers and public associations), create integrated centers of certification and assigning professional qualifications in the regions, encourage the formation of a system of independent assessment of the quality of continuing education and develop competition in the market of continuing education services.

What is significantly new in educational activities is that students become active members of communication: they themselves take part in communication processes and interact with resources. Students need special information support, as they master a significant part of the knowledge themselves. The teacher can analyze these processes, follow them, and exercise control, correcting incorrect, misleading actions of participants in the new form of training, thereby providing constant feedback between all participants in the learning process. In this regard, the presentation of educational material, the form and content of accompanying materials have a new structure for the basis of any multimedia academic and methodological complex. The task of the teacher is to create optimal conditions for students to achieve personal, subject and meta-subject results in training, as well as for the development of students ' information, business and social competencies as the main ones that determine the competitiveness of a professional in the labor market and successful self-realization of a modern person in various fields of activity. Distance learning contributes to the implementation of the modern educational paradigm, the integral components of which are personality-oriented learning, individualization and differentiation of educational activities, the possibility of autonomous learning, self-education and selfdevelopment of students.

\section{Conclusion}

The COVID-19 pandemic has affected the education system, accelerating rapid changes and an active transition of the educational process to online. Digital technologies have changed the concept of advanced education. There are practices of transferring full-time education to distance learning formats (organizing training using online educational platforms, giving classes using social networks, messengers and email). However along with the infrastructure, the greatest difficulty is the readiness of teachers to master digital learning technologies. Communication between students and teachers is shifting to a new format. The pandemic has accelerated the transition of the current education system to digital, and at the same time, it has revealed the problem of professional development of teaching staff, confirming the need for a comprehensive approach to the development strategies of the advanced educational process.

The implementation of distance learning at the University during the pandemic initiated the task of teachers to master and implement information and communication technologies, modern educational and technical means in the educational process, as well as the 
development of distance courses, each of which is a specially designed learning system in the Internet environment.

Digitalization of the educational process involves not only updating the form and content of the traditional education system, but also the reformation of the "tool", requiring new personnel with updated qualifications. In the new environment the teacher is the tool that ensures timely filling of the digital platform with resources for students to obtain knowledge and skills that are in demand in the digital economy.

\section{References}

1. V.I. Kolykhmatov, Digital skills of a modern teacher in the conditions of digitalization of education, P. F. Lesgaft Institute research 9(163), 152-158 (2018)

2. S. Field, M. Kuczera, et. al. Learning for Jobs. Synthetic report of the OECD Reviews of Vocational Education and Training, OECD (2010)

3. Designing Local Skill Strategies, OECD (Paris, 2010)

4. COVID-19 Educational Disruption and Response, UNESCO https://en.unesco.org/covid19/educationresponse (accessed on: 28.09.2020) (Last accessed 13.07.2020)

5. Educause Learning Inititive The next generation digital learning environment. A report on research (2015) https://net.educause.edu/ir/library/pdf/eli3035.pdf (Last accessed 17.07.2020)

6. P. Carter, M. Anderson, E. Mossialos, Health system, public health, and economic implications of managing COVID-19 from a cardiovascular perspective, European Heart Journal, 342 (2020) https://doi.org/10.1093/eurheartj/ehaa342

7. W. Cao, Z. Fang, H. Guoqiang, M. Han, X Xu, J Dong, et al., The psychological impact of the COVID-19 epidemic on college students in China, Psychiatry Research, 287, 112934 (2020) https://doi.org/10.1016j.psychres.2020.112934.

8. OECD, "Tuition fee reforms and international mobility", Education Indicators in Focus, 51 (OECD Publishing, Paris, 2017) https://dx.doi.org/10.1787/2dbe470a-en.

9. D. Uerz, M. Volman, M. Kral, Teacher educators' competences in fostering student teachers' proficiency in teaching and learning with technology: An overview of relevant research literature, Teaching and Teacher Education 70, 12-23 (2018)

10. B. Xu, Nian-Shing, C.G. Chenb, Effects of teacher role on student engagement in WeChat-Based online discussion learning, Computers \& Education 157, 103956 (2020) https://doi.org/10.1016/j.compedu.2020.103956.

11. K. Berhanu, D. Mehretu, A. Ephraim, Technology acceptance model (TAM) inEthiopian agriculture education and research.Global Research Journal of Education 5(1), 531-544 (2017)

12. D.K. Pandey, H.K. De, L. Geetarani, N.A. Singh, Impact of information and communication technologies on agricultural education: Users' perception. Journal of Community Mobilization and Sustainable Development 14(2), 299-304 (2019)

13. N.L. Ritter, Technology acceptance model of online learning management systems inhigher education: A meta-analytic structural equation model, Texas A\&M University Libraries (2017) https://oaktrust.library.tamu.edu/handle/1969.1/166243 (Last accessed 21.06.2020) 
14. R. Scherer, F. Siddiq, J. Tondeur, The technology acceptance model (TAM): Ametaanalytic structural equation modeling approach to explaining teachers' adoption of digital technology in education. Computers\&Education 128, 13-35 (2019)

15. S. Talantis, Y.H. Shin, K. Severt, Conference mobile application: Participant acceptance and the correlation with overall event satisfaction utilizing the technology acceptance model (TAM). Journal of Convention \& Event Tourism 21(2), 100-122 (2020)

16. N.P. Wingo, N.V. Ivankova, J.A. Moss, Faculty perceptions about teaching online: Exploring the literature using the technology acceptance model as an organizing framework. Online Learning 21(1), 15-35 (2017) 